\title{
BRITISH PRESS DISCOURSE: STRATEGIES OF MANIPULATION IN THE BREXIT CAMPAIGN
}

\begin{abstract}
This paper examines the discourse on Brexit in the middle market tabloids the Daily Mail and the Daily Express on a selected corpus consisting of 42,000 words and covering the period from February to June 2016. The study qualifies as linguistic discourse analysis within the qualitative theoretical-methodological approach of CDA. The main objective is to identify and explain the correlation between the employed language and the intended message with special attention to be paid to the assumed preferences of the target audience. The primary focus is on manipulative strategies of positive selfpresentation and negative other-presentation. The final results point at the explicit employment of strategies of negative other- and the subtle and implicit employment of strategies of positive self-presentation. All the findings are examined with respect to the situational and social context.
\end{abstract}

Key words: discourse, tabloids, Brexit, EU, manipulation

\section{Introduction}

The primary function of language is to communicate information. Human language, however, has a whole range of other functions, most of which have to do with the communication process(es). Gee (2001: 1) gathers all these functions into one - "to scaffold the performance of social activities (whether play or work or both) and to scaffold human affiliation within cultures and social groups and institutions." Discourse studies are concerned with the issues of how particular instances of language are employed to exercise these functions and meet the requirements of the (previously) established goals. Language is political everywhere and is always a political issue (see Gee 2001, Chomsky 1979, Chomsky 2004). Politics or "politicality" is deeply entrenched in language-in-use which is, by consequence, a vessel for "politics-inaction". Critical discourse studies (CDA), Fairclough (2003) emphasizes, deal with the structuring of social practices, that is, how we use language to promote hidden agendas

${ }^{*}$ Faculty of Philosophy, University of Sarajevo, Franje Račkog 1, 71000 Sarajevo, Bosnia and Herzegovina; e-mail: dajana.zecic.durmisevic@ff.unsa.ba 
and ideologies that are to result in a particular change, action, or order - in a network of particular social practices. CDA unveils the "politicality" of the language-in-use by representing it for what it is. Hence the claim that CDA is a mode of political action in itself (Chilton 2004).

Much of the scholarly research in the field of CDA is concerned with the language of the media and this is also the case in this paper. The reason is simple - the media never rest, their modes are in perpetual motion and they are a vital means of the large-scale communication in the modern world; they nurture diversity and are the guardians of tolerance (Jenkins 2003). This paper examines the Brexit discourse in the online editions of British middle market tabloids, The Daily Mail and The Daily Express, which, according to a Reuters study (Levy 2016) proved to occupy the leading positions in the category of the "pro-Leave" press. In the UK EU membership referendum in June 2016, the British voted "leave", which is why only the "pro-Leave" press is taken into account in the present study. The goal of this study is to identify and explain the correlation between the employed language and the intended message with special attention to be paid to the assumed preferences of the target audience, which should, in the end, shed some light on the referendum vote result.

The following research question is to be focused on:

- Which strategies of positive self-presentation and negative other-presentation can be identified in the discourse on Brexit in the Daily Mail and the Daily Express?

\section{Literature review}

\subsection{Media discourse: the crucial role of language}

The mass media, as their name suggests, are used to convey a large amount of information to the mass audience. Both journalism as a profession and the media as the means of mass communication have a twofold role: to inform and to affect by informing (Tucaković 2004). The contents of the media, primarily the news media, are supposed to be completely objective and lacking any character, so that the audience is left with enough space to process every new piece of information and make judgements on their own. This means that the reported events in news reports are generally represented as categorical truths - facts - without any intermediate modalities (Fairclough 1989). However, the media in their actual performance challenge this claim, and so do some scholars. The impartiality of news has been considered a myth for a long time now. Fowler (1991) argues that news is a practice that is being constructed by the social and political world on which it reports. What is indeed crucial in mediating reality is, above all, language. Fowler (ibid.) emphasizes that events and ideas are never communicated neutrally, simply because they need to be transmitted through a medium, a vehicle 
of a sort that has its own structural features with particular social values that shape a potential perspective on certain events.

\subsection{Critical discourse analysis}

CDA mostly sees discourse as a social practice (Wodak and Fairclough 1997). In this view, discourse is both socially constitutive and socially conditioned, meaning that it constitutes situations, objects of knowledge, the social identities and relationships between people and groups of people and itself arises from social practices (ibid). It can be concluded that CDA understands discourses as the uses of language that actually serve the organization and structure of social life (Wodak and Meyer 2009). Therefore, one can argue that for CDA, discourse represents either anything or everything from the broad range of layers that spread "from a historical monument, a lieu de mémoire, a policy, a political strategy, narratives in the restricted or broad sense of the term, text, talk, a speech, topic-related conversations, to language per se" (Wodak and Meyer 2009: xxiii). All these social practices are structured by promoting hidden agendas and particular ideologies that are to result in a change, in an action. CDA, therefore, rests upon the notions of discourse, power, dominance, ideology, social inequality and, by all means, upon the position of the discourse analyst in such social relationships (van Dijk 1993). Yet another term that is among the key terms within CDA and closely related to those previously mentioned is manipulation. Van Dijk (2006) offers a triangulated approach to manipulation claiming it is a form of social power abuse, cognitive mind control and discursive interaction exercised through texts, talk and visual messages. The author (ibid.) concludes that manipulation involves power, more precisely abuse of power, that is, domination.

Manipulation as such is considered as a negative social practice, that actually occurs when the manipulated do not perceive the manipulation or the real intentions of the manipulator and this is typically the case when they, in fact, lack the specific knowledge needed to resist manipulative processes (Wodak 1987). Discourse strategies of manipulation are various and evident not only in political, government or media discourse, but in other discourses as well. Van Dijk (2006) mentions overall interaction strategies, such as positive self-presentation and negative other-presentation, topic selection and (de)emphasis of negative/positive topics about Us/Them, word selection, syntactic choices (passive vs. active sentences, nominalizations as prime "agencyconcealers"), rhetorical figures such as metaphor, metonymy, hyperboles, etc. 


\subsection{The media of today and the discourse of diversity: a contemporary dilemma}

Social studies recognized the media as agenda-setters as early as in the 1960 s (Cremades 2007). The process of transformation of the media into exclusive agendasetters can be traced even further back in history (see Wodak and Richardson 2013; Copsey and Richardson 2015, Fairclough 2000). Dominant political and media discourse, as well as public opinion, however, underwent drastic transformations towards the end of the $20^{\text {th }}$ century (Collins 1993; Hollander 1992; Fairclough 2000). Ideological changes were an inevitable part of the global process of "socio-political and economic changes that followed after the demise of state communism and the self-proclaimed victory of capitalism in the early 1990s" (van Dijk 1995a: 27). An important part of these changes is a new relationship between politics, government and the mass media, which resulted in many significant political events becoming media events, thus leading to the "mediatization" of politics and government (Fairclough 2000). The media ended up making the reality "bipolar" - it is Us against Them. We are supporting the "real values", whatever those values are - because they change from one set of ideological assumptions to another, while They are everything opposite, usually regressive, potentially destructive and surely not wanted. A polarization of this sort is evident in the articles on Brexit that comprise the corpus for the analysis in this study and include both the voice of journalists and editors, and the quoted statements of politicians and other public figures.

\subsection{Socio-economic differentiation of the British press}

British newspapers are traditionally classified into "qualities" and "populars" (Jucker 1992). Newspapers like The Guardian or The Times are regarded as quality newspapers because they are devoted to maintaining high standards of reporting, while newspapers like The Sun or the Daily Mirror are said to be populars since they target mass readership (ibid.). Henry (1983) introduced the terms up-market (e.g. The Times, The Independent, The Guardian, The Daily Telegraph), mid-market (e.g. Daily Mail, Daily Express) and down-market (Daily Mirror, The Sun) and this terminology refers to the socio-economic classes of a particular paper's readership. The up-market papers are broadsheets, targeting the middle middle and the upper middle class, whereas the tabloids fit the categories of the mid-market, that are mostly read by the lower middle and the skilled working class, and the down-market newspapers, read by the members of the working class.

Jucker (ibid.) concludes that no paper addresses the population as a whole or it does so, but does not benefit from it and that the British press in fact exaggerates the 
differences in the social class and education of the nation. This conclusion provides a significant context for the present study. The up-markets try to attract the most exclusive readership, mostly the "educated, professional, economically and politically powerful individuals and groups and the content and agenda of broadsheet newspapers reflects the preferences and politics of this predominantly middle and upper class audience" (Richardson 2004: 59). The language of the up-markets tends to be formal and impersonal. The mid-markets and the down-markets, on the other hand, tend to employ language that is rather colloquial, full of idioms, metaphors and, above all, personalized. Turner (2004) suggests that the British tabloids offer almost exclusively news which is utterly personalized and dominated by the actions of well-known people - politicians, celebrities, public officials, etc.

\section{The Brexit vote: a brief overview of the most significant facts}

The very term "Brexit" is used as a shorthand way of referring to the process or event of the United Kingdom leaving the European Union, an economic and political partnership between 28 European countries (including the UK). It was coined by merging the words "Britain" and "exit". The Brexit vote, a referendum, took place on Thursday, 23 June 2016, when the citizens were to decide whether the UK should leave or remain in the EU. More than 30 million people voted, making the referendum turnout $71.8 \%$. The results were $51.9 \%$ to 48.1 in favour of leave. The UK was initially set to leave the European Union by March 2019, but that deadline was extended to the end of January 2020.

The Brexit campaign itself, months prior to the vote, was a rather complex one and aided by the media. In fact, the media played two key roles in the campaign - first, representatives of the two sides attempted to win over public opinion via the media, and second, "the media played an agenda setting role during the campaign by focusing on particular politicians and issues" (Berry 2016: 14). As research from Loughborough University (2016) and Reuters Institute for the Study of Journalism (2016) show, the national press coverage was highly polarized, with pro Brexit and pro EU papers, which produced a "coverage gap" of $60 \%: 40 \%$ in favour of LEAVE campaigners. When these differences are weighted by circulation, the difference extends to $80 \%: 20 \%$ (Deacon, Downey et al. 2016).

The Leave camp employed the classic KISS (Keep It Simple, Stupid) strategy, which meant focusing on simple messages, primarily that of "Take-back-control" the one that resonated with the utmost success across parliamentary fundamentalists, elderly nostalgics, quasi racists and the discontented working poor (Berry 2016). On the other hand, there was the Remain campaign that lacked a clear message about the benefits of staying in the EU that could affect the audience at the rational and 
emotional level (ibid). In other words, "the media operation from Stronger In was unable to compete with the populist message orchestrated by tabloid newspapers" (Wring 2016: 12).

It became more than obvious that most of the UK national press, led by the antiEU Mail, Sun, Express and Telegraph, operated primarily with "distortions, half-truths and outright lies", which further suggests that they indulged in "a ferocious propaganda campaign in which facts and sober analysis were sacrificed to the ideologically driven objectives of editors and their proprietors" (Barnett 2016: 47).

\section{Data and methodology}

The corpus on which this analysis was conducted consists of 65 articles of irregular length, comprising around 42000 words. The corpus consists of two subcorpora - one consisting of 40 online articles (ca. 21000 words) from the Daily Express and the other of 25 online articles from the Daily Mail (ca. 21000 words). The average length of the articles from the Daily Express is ca. 550 words and those from the Daily Mail ca. 800 words. The chosen articles are from the period from 1 February to 23 June 2016. The methodology employed in this study is the linguistic analysis of data within the qualitative approach of CDA and van Dijk's (2004) framework. The chosen articles were read thoroughly and all the examples that support the research question were marked and some of them excerpted for the presentation in the chapter on data analysis and results. Linguistic, i.e. textual, as well as social and situational contexts were taken into account so that the analysis and results could be as objective as possible.

\section{Data analysis and results}

The Daily Mail and the Daily Express were declared biased (i.e. pro-Brexit) by some previous research, which implies that, consequently, the facts coverage and presentation in these tabloids were also biased. This paper focuses on one aspect of the biased coverage - positive self-presentation and negative other-presentation. The Mail and the Express articles are treated as a single corpus because the aim of this study is to find what they have in common and identify generalities; establishing the differences between their discursive strategies is beyond the scope of this research.

\subsection{Positive self-presentation and negative other-presentation strategies}

Numerous instances of positive self-presentation and negative other-presentation strategies employment are evident in the corpus. Before I proceed to present and categorize the most prominent examples, I find it necessary to determine what the Self and the Other, that is We/Us and They/Them in the examined discourse actually 
represent. For the time being, I will define the Self as "the British people who have their country's best interests at heart". This is not the objective Self, but a created Self or an identity imposed by the agenda-setters. More details regarding the peculiarities of this group, the voice of which the Mail and the Express present themselves to be, will be delivered in the sections that follow. The Other are the EU, Brussels (as a metonymic reference to the whole EU), David Cameron and other pro-EU politicians.

\subsubsection{Ideological polarization: Ingroup-outgroup distinction}

Van Dijk (1995b) suggests that the very central characteristics of all ideologies are ingroup-outgroup distinction, differentiation or polarization. There are numerous ways to mark these in a discourse, but scholars agree that the first and most obvious choice is - to make use of personal and possessive pronouns (we-they, us-them, ourtheir etc.) as well as of deictic expression such as here and there. The immediate linguistic context was taken into account with regard to each example, as well as the political and situational context, as suggested by van Dijk:

It is not sufficient to observe, for instance, that political discourse often features the well-known "political" pronoun we. It is crucial to relate such use to such categories as who is speaking, when, where and with/to whom, that is, to specific aspects of the political situation. (van Dijk 2004: 733)

\section{We against Them}

To make a clear distinction between the two realms of values and two ideologies - Ours and Theirs, appears to be one of the primary goals in a biased discourse. It is the first step from which the promotion of Our values and the derogation of Theirs ensues. I chose several of the most prominent examples of polarization by pronouns from the corpus and grouped them into two groups. The first group comprises examples $1-7$, which are further subcategorized into two groups. This group focuses on Us (we, our, here...) and the two subcategories on the victimization and empowerment of $U s$, respectively. The second group focuses on (negative-presentation of) Them (they, their, there...).

(1) Mrs Main, who is campaigning to leave the EU, said: "These figures are startling, and we can now see that we are on an escalator that only leads to more EU with less democratic control." (Daily Mail, March 2016)

(2) Mr Raab said: "At the moment, we can't bar anyone in possession of an $\mathbf{E U}$ passport or identity card unless they represent a genuine, present and sufficiently serious threat to our security." (Daily Mail, June 2016) 
(3) Gleeful Brussels bureaucrats are rolling in cash thanks to Britain's vastly disproportionate contributions to the EU budget, but we get little say in how the undemocratic bloc is run in return. British families have less sway over EU affairs than those in any other nation except France, despite the fact we pump in an eye-watering $\mathbf{1 3 . 3 \%}$ of all the money Brussels receives. (Daily Express, February 2016)

(4) Yes, we have checks at the border because we're not in Schengen. But, what good are checks if we can do so little to act on them? We cannot require those arriving from other EU countries to have a permit issued by the UK, given the scope for fraudulent documents to be issued in other states. We cannot refuse entry to EU citizens producing an EU passport, even though we have no control over the checks made by the country of issue, which we can charitably say are of mixed reliability. (Daily Mail, March 2016)

(5) Free to walk our streets, 1,000 European criminals including rapists and drug dealers we should have deported when they were released from prison (Daily Mail, April 2016)

(6) Andrea Jenkyns, MP for Morley and Outwood (...) said: "As a country, we send $£ 50 \mathrm{~m}$ per day over to the $\mathrm{EU}$, we will be able to invest our money directly where it is needed most in the United Kingdom. It will not solve every challenge, but I feel strongly that it is better used here at home. (...) We can restore the sovereignty of our law-making to Parliament, rather than a distant elite in Brussels which has to take into account conditions and people across the European Union, so much more disparate and varied than our own United Kingdom." (Daily Express, February 2016)

(7) We must all take this opportunity to fight for the best future for the United Kingdom, which is to be free and independent again. The future is in every British citizen's hands. We must seize this moment and stand up for Britain's future as we may not get this chance ever again. (Daily Express, February 2016)

The examples in (1) to (5) are instances of very implicit positive self-presentation and negative other-presentation, in which the italicized instances of the personal pronoun we have an implicature that suggests the powerlessness of the UK that came as a result of EU membership. In other words, the main point in question here is control, or the lack of it. The continuity of such presentation of the Self in the discourse ensures that the sense of impotence on behalf of the British voters is created and that it simultaneously collides with the sense of national pride and (former) glory. These examples are instances of positive self-presentation through victimization. Brexit is presented as a matter of urgency, as suggested by the immediate linguistic context, e.g. we are on an escalator; at the moment; we can't bar anyone, though we have no control 
over the checks made by the country of issue, which we can charitably say are of mixed reliability. The issues of immigration seem to be in focus here.

The examples in (6) and (7) are instances of a somewhat different approach to ideological polarization and positive self-presentation. The Self is now powerful, strong and capable of making changes and, in the end, making history as it used to do in the past. However, the sense of urgency is still present; e.g. we must all take this opportunity to fight for the best future for the United Kingdom, which is to be free and independent again; we must seize this moment. It is about restoring sovereignty, taking back control over our money. The sense of "uniqueness" of the British nation is evoked, too - a distant elite in Brussels which has to take into account conditions and people across the European Union, so much more disparate and varied than our own United Kingdom. It appears that it is about the superiority and conditional inferiority caused by the "elitist" and "undemocratic" EU at the same time.

(8) Ms Mordaunt claimed Brexit would be "more in sorrow than in anger" for other EU member states, adding: "They will understand that, from time to time, the oldest, most stable and most successful country in Europe has a duty to remind a European Union barely 50 years old that government is the servant, and not the master, of the people." (Daily Express, February 2016)

(9) Mr Cameron's approach sparked outrage within the Tory party, with MP Liam Fox blasting the tactic. He said: "It seems Project Fear has gone international. When will it dawn on the Remain campaign that the British people don't like being lectured by foreign leaders? They would be better off making the positive case for the EU, which they seem terrified of doing." (Daily Express, April 2016)

(10) Vested interests rarely like innovation. Nor does the EU, which is, by its nature, hostile to anything new or different. Existing elites fear that the creative destruction of new inventions might jeopardise their position. They therefore lobby to keep things more or less as they are. (Daily Mail, April 2016)

(11) David Cameron has put national security at the heart of his campaign for Britain to remain in the European Union. (Daily Mail, February 2016)

(12) The results of the poll came as David Cameron battled to save his renegotiation deal at a crunch summit in Brussels. (Daily Express, February 2016)

In the examples from (8) to (12), the EU, David Cameron and other pro-EU politicians are presented as the Other - the (national) enemy. Here we can see some instances of outgroup derogation - Their group is either associated with negative deeds (e.g. Existing elites fear that the creative destruction of new inventions might 
jeopardise their position. They therefore lobby to keep things more or less as they are.) or utter incompetence, both of which make Them incapable of leading the British people (e.g. They would be better off making the positive case for the EU, which they seem terrified of doing). In addition, Cameron is presented with a particularly strong bias the negotiations he conducted were described as only his. In this way, Cameron was distanced from the country and people he, de facto, represented.

\section{The UK against the EU: A fight for democracy and justice}

Ideological polarization usually rests upon legitimizing and praising Our deeds and delegitimizing and discrediting Theirs, placing emphasis on Our good deeds and Their bad deeds. In examples 13-14, the freedom of movement guaranteed by the EU was presented as a threat to Britain's security which was a way of discrediting the EU as well as an implicit discrediting of all immigrants as they are referred to synonymously as a security threat:

(13) Terrorists can buy EU passports for just 4,000 Euros proving the security threat caused by Brussels (Daily Mail, June 2016)

(14) (...) freedom of movement rules was a threat to Britain's security (Daily Mail, June 2016)

The further discrediting of the EU was done by presenting every message from Brussels as a threat. In the following examples, the noun threat has somewhat different semantic connotations than in the previous examples; the threats here are not the "imminent danger", but "the way the EU officials are".

(15) Deserters will not be welcomed with open arms: Brussels chief issues stark threat that EU will punish Britain if we vote to leave (Daily Mail, May 2016)

(16) Jean-Claude Juncker warned that Germany, France and other states would not "bend over backwards" to help if the UK abandoned the union. It is the bloodcurdling threat about the consequences of cutting ties with Brussels. (Daily Mail, May 2016)

(17) Latest threat about the EU's response to a Leave vote after French finance minister warned we would be "killed" in trade negotiations (Daily Mail, May 2016)

(18) Tory MEP David Campbell Bannerman last night said the secret court threat demonstrated how the Commission was holding back plans that will negatively affect Britain until after the referendum vote (Daily Mail, April 2016) 
A further and broader analysis confirms the assumption that nouns Europe, EU, Brussels, as well as adjective European are presented with negative connotations that are retrievable from the immediate linguistic context, which is a way of discrediting and delegitimizing everything that is related to the EU. Here are some examples:

(19) Dominic Raab launched a scathing attack on current EU rules, which he said allowed terror suspects to "waltz" into Britain because they have a "free pass" to roam around Europe under freedom of movement rules. (Daily Mail, June 2016)

(20) Former shadow home secretary David Davis said: "The argument that Europe is somehow improving our security is falling apart in the Government's hands." (Daily Mail, May 2016)

(21) (...) the European Court is seeking greater controls over our intelligence and security services (Daily Mail, May 2016)

(22) Brussels officials are secretly plotting to haul Britain before the EU courts (Daily Mail, April 2016)

(23) Free to walk our streets, 1,000 European criminals including rapists and drug dealers we should have deported when they were released from prison (Daily Mail, April 2016)

(24) (...) the EU was lobbied by a vested interest and adopted rules that increased air pollution and led to the needless deaths of thousands of European citizens. (Daily Mail, April 2016)

(25) Mr Miliband admitted that many Labour voters were concerned the danger that Eastern European migrants were undercutting their wages... (Daily Mail, March 2016)

(26) BRITONS have less influence in Brussels than the people of almost any other country in Europe despite the $\boldsymbol{E} \boldsymbol{U}$ squeezing $\boldsymbol{U} \boldsymbol{K}$ families for an astonishing $£ 1,000$ a year, it can be revealed today. (Daily Express, February 2016)

(27) The revelations raise serious concerns about the undemocratic nature of the Brussels project and prove that this summer's referendum will be a oncein-a-lifetime opportunity for Britain to decide on its relationship with Europe. (Daily Express, February 2016)

(28) “Ridiculous" $\boldsymbol{E} \boldsymbol{U}$ restrictions stopped life-saving cancer research, claims leading expert (Daily Express, March 2016)

(29) Rise of EUROPEAN jihadis: EU admits ISIS is exploiting refugee crisis to infiltrate Europe (Daily Express, April 2016)

(30) A LEADING Tory minister has claimed the "spirit of Dunkirk" will see Britain thrive outside of the crisis-stricken EU. (Daily Express, February 2016) 
The previous examples show that the European Union, as well as those who support it, are associated only with negative notions, such as danger $(23,24)$, insecurity $(20,29,30)$, lack of freedom and undemocratic operations $(21,22,27)$ etc. Therefore, the ideological polarization is at work with claims that Europe operates by issuing continuous threats (13-18), burdening the UK with the red tape that puts (British) lives in danger (28), allowing terrorists, criminals to "waltz" into Britain (19), enabling foreign workers to enter the country (25) etc. The message is simple - Europe is ridiculous, dysfunctional, undemocratic and dangerous. Britons, on the other hand, are presented as just and exhausted taxpayers constantly under threat by the EU rules. Our ideology is the ideology of democracy, justice and peace, while Theirs is one of injustice and terror. Here, we encounter additional examples of implicit positive selfpresentation and very explicit negative other-presentation.

\section{We against David Cameron: a fight for the "Truth" (lexical choice)}

When it comes to David Cameron, whom the Mail and the Express did not support as he was backing the Stronger In option, he was usually presented with a strong and obvious bias, and I will pinpoint some of the most prominent examples in both the newspapers that also confirm that the ideological polarization was one of the interaction strategies and manipulative devices employed in the discourse. Unlike in examples $8-12$, the analysis here is not focused on ideological polarization by personal pronouns, but on the immediate "actor description" or lexical choice (see van Dijk 2004).

(31) David Cameron has "colluded" with the EU and is "lying" to British voters over the EU, Iain Duncan Smith blasted today. (Daily Mail, June 2016)

(32) Mr Cameron also faced anger from Tory Eurosceptics, who accused him of ditching controversial reforms in a desperate bid to keep Britain in the EU as today's Queen's Speech unveiled a gimmick-heavy government programme. (Daily Mail, May 2016)

(33) David Cameron defends "One Nation" Queen's Speech amid claims he scrapped flagship reforms for a series of lightweight gimmicks in a desperate scramble to avoid Brexit (Daily Mail, May 2016)

(34) Mr Cameron arrived at the meeting to a muted welcome but left with his arm around Eurosceptic Philip Davies. (Daily Mail, February 2016)

(35) The vast majority of Conservative activists are set to defy David Cameron and support Brexit, a survey suggests. (Daily Mail, February 2016)

(36) David Cameron struggles to convince leading members of his Government he has won a good deal from Brussels. (Daily Express, February 2016) 
(37) "Scaremongering" Cameron claims Brexit will "trigger economic shock" across Britain (Daily Express, March 2106)

(38) Shameless Cameron uses nuclear summit to drum up support for Britain sticking with EU (Daily Express, April 2016)

These examples demonstrate the clear intention of discrediting the opponent and creating an image of social reality in two colours - black and white, which in the end is the concept of ideological polarization in itself. Furthermore, the Us-Them polarization tells us about the existence of certain opposing ideologies created by the opposed groups and used for identification. One needs to have a place within a particular societal structure and establish relations with the in-group members. David Cameron was excluded from that group despite the fact that he was the PM at the time. Throughout the discourse, he is presented as a scaremongering (37), shameless (38), desperate $(32,33)$ pro-EU politician who is struggling (36) with his anti-EU party fellows and facing either anger (32) or muted welcomes (34) by his people.

\section{Key findings and conclusion}

This study showed that the mid-market tabloids Daily Mail and Daily Express did in fact provide a biased account of the facts regarding the Brexit referendum and the European Union membership prospects during the Brexit campaign, months prior to the Brexit vote. Both newspapers employed various interaction strategies of positive self-presentation and negative other-presentation, which in itself proves the biased coverage. The main message that one could retrieve from the material analysis is that the British people should regain control of their country because EU membership does not benefit them. The critical discourse analysis points at the lack of objective arguments that could stand behind the idea of Britain's potential exit from the EU. As Conboy (2006) suggested, it could be concluded that complex arguments collapsed into a one-linear point of view. This, again, takes us back to the above mentioned manipulative (interaction) strategies exercised by the dominant, more powerful group, i.e. the media that are in possession of the means of mass communication, in order to instil a particular ideology into the targeted readership and provoke the desired action (of voting Leave). In other words, instead of arguments, the Mail and the Express relied on manipulation. Furthermore, a deeper insight into the results brings me to the conclusion that the main overall strategy of manipulation was, in fact, negative other-presentation which, in itself, served as the basis for positive self-presentation. The Other is directly presented as undemocratic, unjust, tyrannical, unsafe and costly, while the Self is implicitly presented as opposite to the Other. The implicit positive self-presentation is usually delivered through the victimization of the Self that was 
to target the emotion of national pride, sometimes to arouse panic, but also through moral-raising messages of hope that could be summarized as - We can do this for We must do it. A message as simple as this one resonated with the utmost success across parliamentary fundamentalists, elderly nostalgics, quasi racists and the discontented working poor (Berry 2016).

The fact that strategies of positive self-presentation and negative otherpresentation largely contribute to a biased account of the facts in media discourse is a starting point which this study also confirms. In the case of this research, they created one version of reality that was not to be questioned, which undoubtedly proves the ideological work of the chosen discourse. CDA studies, including this one, point at this social phenomenon by unmasking the authentic identity of social actors, i.e. discourse participants, and revealing the power dynamics between them. In this study, Conservative (pro-Leave) politicians, together with the traditionally Conservative tabloids the Daily Mail and the Daily Express, which actively endorse Eurosceptic and right-wing agendas, are proven to be the discourse actors with the highest authority. The oppressed are the Others and they are actively discriminated against throughout the discourse. The immediate victims of manipulation are, in fact, the readers of particular profiles, who are being kept voluntarily obedient to the idea of Euroscepticim. Those are, once again, elderly nostalgics, fundamentalists, the working class - all of whom mostly belong to the lower middle class, which is, in the end, the target audience of the mid-market newspapers in Britain.

\section{References}

Barnett, S. (2016). How Our Mainstream Media Failed Democracy. In: J. Daniel et al. (eds.), EU Referendum Analysis 2016: Media, Voters and the Campaign Early reflections from leading UK academics, Poole: The Centre for the Study of Journalism, Culture and Community and Bournemouth University, 47-48.

Berry. M. (2016). Understanding the Role of the Mass Media in the EU referendum. In: J. Daniel et al. (eds.), EU Referendum Analysis 2016: Media, Voters and the Campaign Early reflections from leading UK academics, Poole: The Centre for the Study of Journalism, Culture and Community and Bournemouth University, $14-15$.

Chilton, P. (2004). Analysing Political Discourse: Theory and Practice. London and New York: Routledge.

Chomsky, N. (1979). Language and Responsibility. New York: Pantheon.

Chomsky, N. (2004). Language and Politics. Edinburgh and London: AK Press. 
Collins, P. (1993). Ideology after the Fall of Communism. Boston: Bowerdean Press. Conboy, M. (2006). Tabloid Britain: Constructing Community Through Language. London and New York: Routledge.

Copsey, N. and J. E. Richardson (eds.) (2015). Cultures of post-war British fascism. London and New York: Routledge.

Cremades, P. S. (2007). An Overview of the Critical Discourse Analysis Approach to Mass Communication. In: J. M. Bernardo et al. (eds.), Critical Discourse Analysis of Media Texts, Valencia: University of Valencia, 17-38.

Deacon, D., J. Downey et al. (2016). The Narrow Agenda: How the News Media Covered the Referendum. In: J. Daniel et al. (eds.), EU Referendum Analysis 2016: Media, Voters and the Campaign-Early reflections from leading UK academics, Poole: The Centre for the Study of Journalism, Culture and Community and Bournemouth University, 34-35.

Fairclough, N. (2003). Analysing Discourse. London, New York: Routledge.

Fairclough, N. (1989). Language and Power. London: Longman.

Fairclough, N. (2000). New Labour, New Language? London and New York: Routledge. Fowler, R. (1991). Language in the News. London and New York: Routledge.

Gee, J. P. (2001). An Introduction to Discourse Analysis. London and New York: Routledge.

Henry, H. (1983). Are the national newspapers polarizing? Admap, 19, 484-491. Hollander, P. (1992). Decline and Discontent: Communism and the West Today. New Brunswick: Transaction.

Jenkins, S. (2003). Foreword. In: J. Aitchison and D. Lewis (eds.), New Media Language, London and New York: Routledge, 3-6.

Jucker, A. (1992). Social Stylistics: Syntantic Variation in British Newspapers. New York: Mouton de Gruyter.

Levy, D. et al (eds.) (2016). UK Press Coverage of the EU Referendum. Oxford: Reuters, Prime Research.

Richardson, J. (2004). (Mis)Representing Islam: The Racism and Rethoric of British Broadsheets Newspapers. Amsterdam: John Benjamins Publishing Company.

Tucaković, Š. (2004). Leksikon mas-medija. Sarajevo: Prosperitet.

Turner, G. (2004). Understanding Celebrity. London: SAGE.

van Dijk, T. (1993). Principles of Critical Discourse Analysis. Discourse \& Society, 4, 249-283.

van Dijk, T. (1995a). The Mass Media Today: Discourses of Domination or Diversity? Javnost - The Public, 2, 27-45.

van Dijk, T. (1995b) Ideological discourse analysis. In V. Elija et al. (eds.), The New Courant. Helsinki: University of Helsinki, 135-161. 
van Dijk, T.A. (2004). Politics, ideology and discourse. (20 June 2019) $<$ http://www.discourse-in-society.org/teun.html $>$.

van Dijk, T. (2006). Discourse and manipulation. Discourse \& Society, 17, 359-383.

Wodak, R. (1987). And Where Is the Lebanon? A Socio-Psycholinguistic Investigation of Comprehension and Intelligibility of News. Text, 7, 377-410.

Wodak, R. and N. Fairclough (1997). Critical Discourse Analysis. In: T. van Dijk (ed.), Discourse as Social Interaction. London: SAGE, 258-284.

Wodak, R. and M. Meyer (eds.) (2009). Methods for Critical Discourse Analysis. London: SAGE.

Wodak, R. and J. Richardson (eds.) (2013). Analysing Fascist Discourse: European Fascism in Text and Talk. New York and London: Routledge.

Wring, D. (2016). From Super-Market to Orwellian Super-State: The Origins and Growth of Newspaper Scepticism. In: J. Daniel et al. (eds.), EU Referendum Analysis 2016: Media, Voters and the Campaign: Early reflections from leading UK academics. Poole: The Centre for the Study of Journalism, Culture and Community and Bournemouth University, 12-13.

\section{Appendix}

\section{CORPUS $^{2}$}

Daily Express (12 February 2016, 15 February 2016, 17 February 2016, 18 February 2016, 20 February 2016, 23 February 2016, 26 February 2016, 2 March 2016, 3 March 2016, 4 March 2015, 6 March 2016, 11 March 2016, 18 March 2016, 24 March 2016, 2 April 2016, 4 April 2016, 5 April 2016, 6 April 2016, 8 April 2016, 13 April 2016, 3 May 2016, 4 May 2016, 5 May 2016, 6 May 2016, 7 May

2016, 10 May 2016, 23 May 2016, 1 June 2016, 3 June 2016, 6 June 2016, 20 June 2016)

DailyMail(23February2016,24February2016,25February2016,6March2016,22 March 2016, 28 March 2016, 30 March 2016, 4 April 2016, 11 April 2016, 22 April 2016, 26 April 2016, 11 May 2016, 18 May 2016, 20 May 2016, 21 May 2016, 8 June 2016, 23 June 2016)

\footnotetext{
${ }^{2}$ Some dates comprise several articles.
} 